INTERNATIONAL JOURNAL OF MULTidisciplinARY RESEARCH AND ANALYSis

ISSN(print): 2643-9840, ISSN(online): 2643-9875

Volume 05 Issue 01 January 2022

DOI: 10.47191/ijmra/v5-i1-01, Impact Factor: 6.072

Page No.- 01-12

\title{
Pantawid Pamilyang Pilipino Program (4Ps) Beneficiaries: An Analysis of Their Satisfaction Levels
}

\author{
Nelly H. Parreño ${ }^{1}$, Dafe Eramis-Eslabon ${ }^{2}$ \\ ${ }^{1}$ Research DirectorCollegio Sta. Anna de Victorias \\ ${ }^{2}$ Faculty MemberColegio Sta. Anna de Victorias
}

\begin{abstract}
This study examined the difference in the satisfaction level of 4Ps beneficiaries in Barangay VI, Victorias City, Negros Occidental, Philippines between the year 2015 and year 2020. The design of the study used a descriptive comparative method of research. The participants were 216 from 2015, 250 from 2020, and were official 4Ps beneficiaries of Barangay VI, Victorias City, Negros Occidental in the specified years. Results were analyzed with frequency, percentage, mean, and T-test. The findings revealed that the majority of them were above 30 years old with 349 (74.89\%), female with 425 (91.20\%), married with 359 (77.04\%), laborers with $268(57.51 \%)$, with 1-3 number of children with $261(56 \%)$, and high school level of educational attainment with 284 (60.95\%). Further, it indicated that there was an increasing trend in the 4Ps parent-beneficiaries in 2020 with the following: above 30 years old $(41.2 \%)$ widow $(7.1 \%)$, single parent $(9.9 \%)$, no work $(17.4 \%)$, laborers $(8.8 \%)$, collegelevel $(4.8 \%)$ and college graduates $(0.1 \%)$. It revealed the decreasing trend in the year 2020 with the following 4 Ps parentbeneficiaries: 30 years old and above (46.8\%) and married (13.5\%). The satisfaction level of 4Ps beneficiaries to CCT has significantly increased to a high level of satisfaction by 2020. There was a significant difference in the satisfaction level of 4Ps parent- beneficiaries to the CCT program which revealed that the satisfaction level survey was higher in 2020 than in 2015 especially in terms of health grants and education grants. Lastly, it was recommended to provide sustainable programs that would enhance the living conditions and nutrition grants of locals.
\end{abstract}

KEYWORDS: Include at least 5 to 6 keywords or phrases

\section{INTRODUCTION}

Pantawid Pamilyang Pilipino is a Philippine government assistance program for extremely poor families. This program provides health care, nutrition, family development, and education to low-income families with children aged 0 to 14 . It has two objectives: 1) to provide economic assistance to satisfy their immediate needs, and 2) to promote social development by investing in human capital to break the cycle of poverty (Agbon, Nolasco-Amadora, Aguilar, Abellanosa, \& Ligaton, 2013). It aspires to end severe poverty in the Philippines by investing in health and education, especially for children aged 0 to 18 . It is modeled after similar projects in other developing countries, such as Bolsa Familia in Brazil, Familias en Accion in Columbia, and Oportunidades in Mexico (Defensor). At this time, the 4Ps program serves 4,326,208 households in 17 regions, 79 provinces, 143 cities, and 1,484 municipalities (4Ps).

This government program is still affecting the lives of poor people across the country, especially the 463 Indigenous Peoples (IT) of the Ata tribe/family in Mabinay, Negros Oriental. In 2015, it covered IPs who received modified conditional cash transfers for indigenous peoples (MCCT-IP), notably those who lived in geographically isolated and disadvantaged areas (GIDAs). It also strives to give families with a holistic change through family development Sessions (FDS), which have a higher rate of developing parent leaders in the community, according to Newman (2020).

Along this line, several studies have been conducted showing that, while life satisfaction is not always high in countries with higher earnings, income has a greater impact on the well-being of impoverished people than it does on the well-being of rich people (Bayram, Aytac, Aytac, Sam, \& Bilgel, 2012). 


\section{Pantawid Pamilyang Pilipino Program (4Ps) Beneficiaries: An Analysis of Their Satisfaction Level}

Most research on the Pantawid Pamilyang Pilipino Program concentrated on its sociological and economic components. As a result, the researchers chose this time to pursue a psychological approach. The focus of this study will be on a satisfaction survey of 4Ps recipients with the following objectives: (1) determine the demographic profiles of the 4Ps beneficiaries in terms of age, sex, civil status, occupation, number of children, and educational qualification; (2) determine the satisfaction levels of the 4Ps beneficiaries in health grant, nutrition grant, education grant, and living condition.

\section{METHODOLOGY}

\section{Research Design}

This study aimed to determine the satisfaction levels of the 4Ps beneficiaries of Brgy VI, Victorias City, Philippines; hence the descriptive method of research was used. According to Latin and Berg (2004), descriptive research is typified by observations or descriptions of the status of a condition or situation. Investigators using this method do not manipulate variables or make things happen.

\section{Participants of the Study}

The participants of the study were the 4Ps beneficiaries of Brgy VI, Victorias City, Philippines. These participants were grouped according to their demographic profile such as their age, sex, civil status, occupation, number of children, and educational qualification.

\section{Research Instrument}

The research instrument used in this study consisted of two main parts namely:

\section{Part I. Demographic Profile}

Part I of the research instrument determined the demographic profile of the 4Ps participants. This includes participants' name which is optional, age, sex, civil status, occupation, number of children, and educational qualification.

\section{Part II. Level of Satisfaction Survey}

This study made use of self-made questionnaire which was used in the 2015 satisfaction survey. Such questionnaires used a Likert scaling system to measure the level of satisfaction on a 4Ps program or CCT. The second part of the research instrument determined the satisfaction levels of 4 ps beneficiaries in health grants, nutrition grants, education grants, and living condition. Since the instrument was adapted in 2015 , it has undergone validity and reliability.

\section{Statistical Analysis of the Data}

To answer the proposed problems, the researcher utilized the descriptive statistics. For problem 1 which determined the demographic profile of the participant, frequency and percentage was used. For problem 2, which determined the satisfaction levels of the 4Ps participants, mean was used. To interpret the satisfaction levels of the 4Ps participants, the following scale was used: 4.21-5.00 (Very highly satisfied); 3.41-4.2 (Highly satisfied); 2.61-3.40 (Satisfied), 1.81-2.60 (Fairly satisfied); $1.00-1.80$ (Not satisfied).

\section{Ethical Considerations}

The researchers included statements that consider the following: Republic Act 10173 - Data Privacy Act of 2012, informed consent, the anonymity of respondents, the confidentiality of data; and disposal of survey materials. It was also emphasized that their participation was voluntary and all the data taken from them were treated with high confidentiality. 
Pantawid Pamilyang Pilipino Program (4Ps) Beneficiaries: An Analysis of Their Satisfaction Level

\section{RESULTS AND DISCUSSION}

Table 1: Demographic Profile of the 4Ps Beneficiaries

2015

2020

Difference

\begin{tabular}{|c|c|c|c|c|c|}
\hline \multicolumn{6}{|l|}{ Arge } \\
\hline 30 and above & $\begin{array}{c}114 \\
{[52.8 \%]}\end{array}$ & $235[94 \%]$ & $\begin{array}{c}349 \\
{[74.89 \%]}\end{array}$ & $41.2 \%$ & Increase \\
\hline Belown 30 & $\begin{array}{c}102 \\
{[47.2 \%]}\end{array}$ & $15[6 \%]$ & $\begin{array}{c}117 \\
{[25.11 \%]}\end{array}$ & $41.2 \%$ & Decrease \\
\hline \multirow{2}{*}{\multicolumn{6}{|c|}{ Sex }} \\
\hline & & & & & \\
\hline Female & $\begin{array}{c}200 \\
{[92.6 \%]}\end{array}$ & $225[90 \%]$ & $\begin{array}{c}425 \\
{[91.20 \%]}\end{array}$ & $2.6 \%$ & Decrease \\
\hline $\begin{array}{l}\text { Mulale } \\
\text { Total }\end{array}$ & $\begin{array}{c}16[7.4 \%) \\
216(100 \%)\end{array}$ & $\begin{array}{c}25[10 \%] \\
250(100 \%]\end{array}$ & $\begin{array}{l}41[8.80 \%] \\
466[100 \%)\end{array}$ & $2.6 \%$ & Increase \\
\hline \multicolumn{6}{|l|}{ Civil Status } \\
\hline Mularied & $\begin{array}{c}182 \\
{[84.3 \%]}\end{array}$ & $\begin{array}{c}177 \\
{[70.8 \%]}\end{array}$ & $\begin{array}{c}359 \\
{[77.04 \%]}\end{array}$ & $13.5 \%$ & Decrease \\
\hline Separated & $12[5.6 \%]$ & $11[4.4 \%]$ & $23[4.94 \%]$ & $1.2 \%$ & Decrease \\
\hline Inlidoun & $14[6.5 \%]$ & $34[13.6 \%]$ & $48[10.30 \%]$ & $7.1 \%$ & Increase \\
\hline Single Parent & $8[3.7 \%]$ & $28[13.6 \%)$ & $36[7.73 \%]$ & $9.9 \%$ & Increase \\
\hline \multicolumn{6}{|l|}{ Occupation } \\
\hline Laborer & $\begin{array}{c}114 \\
{[52.8 \%]}\end{array}$ & $\begin{array}{c}154 \\
{[61.6 \%]}\end{array}$ & $\begin{array}{c}268 \\
{[57.51 \%]}\end{array}$ & $8.8 \%$ & Increase \\
\hline Driver & $57[26.4 \%]$ & $25[10.0 \%]$ & $82[17.60 \%]$ & $16.4 \%$ & Decrease \\
\hline viendor & $35[16.2 \%]$ & $16[6.4 \%]$ & $51[10.94 \%)$ & $9.8 \%$ & Decrease \\
\hline No tflork & $10[4.6 \%]$ & $55[22 \%]$ & $65[13.95]$ & $17.4 \%$ & Increase \\
\hline \multicolumn{6}{|l|}{$\begin{array}{l}\text { Number } \\
\text { Children }\end{array}$} \\
\hline $\begin{array}{c}\text { Childiren } \\
1-3\end{array}$ & $\begin{array}{c}124 \\
{[57.4 \%]}\end{array}$ & $\begin{array}{c}137 \\
{[54.8 \%]}\end{array}$ & $261[56 \%]$ & $2.6 \%$ & Decrease \\
\hline 4 and above & $92[42.6 \%]$ & $\begin{array}{c}113 \\
{[45.2 \%]}\end{array}$ & $205[44 \%]$ & $2.6 \%$ & Increase \\
\hline \multicolumn{6}{|l|}{$\begin{array}{l}\text { Educational } \\
\text { Qualification }\end{array}$} \\
\hline Elementary & $66[30.6 \%]$ & $67[26.8 \%]$ & $\begin{array}{c}133 \\
{[28.54 \%]}\end{array}$ & $3.8 \%$ & Decrease \\
\hline High School & $\begin{array}{c}133 \\
{[61.1 \%]}\end{array}$ & $151[60.4 \%]$ & $\begin{array}{c}284 \\
{[60.95 \%]}\end{array}$ & $0.7 \%$ & Decrease \\
\hline $\begin{array}{l}\text { College Level } \\
\text { College }\end{array}$ & $\begin{array}{l}13(6 \%) \\
4[1.9 \%)\end{array}$ & $\begin{array}{c}27[10.8 \%] \\
5[2 \%]\end{array}$ & $\begin{array}{l}40[8.58 \%] \\
9[1.93 \%]\end{array}$ & $\begin{array}{l}4.8 \% \\
0.1 \%\end{array}$ & $\begin{array}{l}\text { Increase } \\
\text { Increase }\end{array}$ \\
\hline Graduate & & & & & \\
\hline Total & $216[100 \%]$ & $250[100 \%]$ & $466[100 \%]$ & & \\
\hline
\end{tabular}

Table 1 shows the demographic profile of the 4Ps beneficiaries of Barangay VI, Victorias City, Negros Occidental during 2015 and 2020. When grouped according to age, there were114 (52.8\%) ages 30 and above and $102(47.2 \%)$ for below 30 in 2015 . In the year 2020, it shows that there were 235 (94\%) ages 30 and above and 15 (6\%) ages below 30 years old. It signifies that some of 30 years old and above 4Ps beneficiaries have increased in 2020. Below 30 years old significantly decreased in 2020. When grouped according to sex, there were 200 (92.6\%) females in 2015 and 225 (90\%) in 2020. For male beneficiaries, there were $16(7.4 \%)$ in 2015 and $25(10 \%)$ in 2020 . When grouped according to civil status, married with 182 (84.3\%), separated with 12 (5.6\%), a widow with 14 (6.5\%), single parent with 8 (3.7\%), and total sample size with $216(100 \%)$ in 2015. In the year 2020, it showed that 4Ps beneficiaries who were married were 177 (70.8\%), separated with 11 (4.4\%), widows with 34 (13.6\%), and single parents with 28 (13.6\%). When it comes to occupation, in the year 2015 there were 114 (52.8\%) for laborers, drivers with 57 (26.4\%), vendors with 35 (16.2\%), no work 10 (4.6\%). However, in the year 2020, there were 154 (61.6\%) for laborers, drivers with $25(10.0 \%)$, vendors with $16(6.4 \%)$, and no work with $55(22 \%)$. When grouped according to the number of children, it shows that in 2015, 4Ps beneficiaries with 1-3 children were 124 (57.4\%) and those with beneficiaries with 4 children and above were 92 (42.6\%).

However, in the year 2020, it showed that beneficiaries with 1-3 children were 137 (54.8\%) and 4 children and above with 113 (45.2\%). When grouped according to educational qualification, it shows that in 2015, 4Ps beneficiaries with educational qualification of elementary were $66(30.6 \%)$, high school with $133(61.1 \%)$, college-level with 13 (6\%), and graduated college with 4 (1.9\%). However, in the year 2020, it showed that 4Ps beneficiaries with educational qualification of elementary were 67 (26.8\%), high school with $151(60.4 \%)$, college-level with $27(10.8 \%)$, and graduated college with 5 (2\%). Overall, the majority of 4Ps beneficiaries from 2015 to 2020 were those who were below 30 with 337 (72.3\%), female with 425 (91.20\%), married with $359(77.04 \%)$, a laborer with 268 (57.51\%), 1-3 number of children with 261 (56\%) and those who have high school educational attainment with 284 (60.95\%). 
Pantawid Pamilyang Pilipino Program (4Ps) Beneficiaries: An Analysis of Their Satisfaction Level

Table 2. Satisfaction Level of the 4Ps beneficiaries During the Year 2015 and Year 2020

\begin{tabular}{lcccc}
\hline & \multicolumn{2}{c}{ Year 2015 } & Year 2020 & \\
\hline Areas & Mean & $\begin{array}{c}\text { Interpretatio } \\
\mathbf{n}\end{array}$ & Mean & Interpretation \\
Health & 3.38 & Satisfied & 3.44 & Highly Satisfied \\
Nutrition & 3.31 & Satisfied & 3.40 & Satisfied \\
Education & 3.35 & Satisfied & 3.49 & Highly Satisfied \\
Living condition & 3.00 & Satisfied & 3.37 & Satisfied \\
When Taken as a & 3.26 & Satisfied & 3.43 & Highly Satisfied \\
Whole & & & & \\
\hline
\end{tabular}

Table 2 shows the satisfaction level of 4Ps beneficiaries of Barangay VI, Victorias City, Negros Occidental during 2015 and 2020. Overall, in 2015 it shows that the satisfaction level of 4Ps beneficiaries was $M=3.26$ interpreted as satisfied. In terms of health grant, it was $M=3.38$, nutrition grant with $M=3.31$, education grant with $M=3.35$, and living condition with 3.00 . This indicated that in terms of health grant, nutrition grant, education grant, living condition and overall level of satisfaction to CCT by 4Ps parent-beneficiaries were all satisfied. However, in the year 2020, it shows that the overall satisfaction level to CCT was 3.43 . In terms of health grant, it was $M=3.44$, nutrition grant with $M=3.40$, education grant with $M=3.49$, and living condition with 3.37 . It further indicated that the overall satisfaction level of 4Ps beneficiaries to CCT was highly satisfied. In terms of nutrition grant and living condition were satisfied but highly satisfied in terms of health and living condition grants.

Table 3. Satisfaction Level of the 4Ps beneficiaries During the Year 2015 and Year 2020 when Grouped According to Age

\begin{tabular}{|c|c|c|c|c|}
\hline & \multicolumn{2}{|r|}{2015} & \multicolumn{2}{|r|}{2020} \\
\hline $\begin{array}{l}\text { Areas and } \\
\text { Variables }\end{array}$ & Mean & $\begin{array}{c}\text { Verbal } \\
\text { Interpretation }\end{array}$ & Mean & $\begin{array}{c}\text { Verbal } \\
\text { Interpretation }\end{array}$ \\
\hline Health & & & & \\
\hline Below 30 & 3.45 & Highly Satisfied & 3.40 & Satisfied \\
\hline 30 and & 3.31 & Satisfied & 3.44 & Satisfied \\
\hline Above & & & & \\
\hline As A Whole & 3.31 & Sotisfied & 3.44 & Sotisfied \\
\hline Nutrition & & & & \\
\hline Below 30 & 3.39 & Satisfied & 3.46 & Highly Satisfied \\
\hline $\begin{array}{l}30 \text { and } \\
\text { Above }\end{array}$ & 3.23 & Satisfied & 3.39 & Satisfied \\
\hline $\begin{array}{l}\text { As } A \text { Whole } \\
\text { Education }\end{array}$ & 3.31 & Satisfied & 3.43 & Satisfied \\
\hline Below 30 & 3.37 & Satisfied & 3.46 & Highly Satisfied \\
\hline $\begin{array}{l}30 \text { and } \\
\text { Above }\end{array}$ & 3.32 & Satisfied & 3.49 & Highly Satisfied \\
\hline $\begin{array}{l}\text { As A Whole } \\
\text { Living } \\
\text { Condition }\end{array}$ & 3.35 & Satisfied & 3.48 & Highly Satisfied \\
\hline Below 30 & 3.00 & Satisfied & 3.33 & Satisfied \\
\hline $\begin{array}{l}30 \text { and } \\
\text { Above }\end{array}$ & 2.99 & Satisfied & 3.37 & Satisfied \\
\hline As $A$ Whole & 3.00 & Satisfied & 3.35 & Satisfied \\
\hline
\end{tabular}

Table 3 shows the satisfaction level of the 4Ps beneficiaries of Barangay VI, Victorias City, Negros Occidental during 2015 and 2020 according to age. Overall, the satisfaction level of 4Ps beneficiaries in 2015 with below 30 was satisfied in terms of nutrition grant with $M=3.39$, education grant with $M=3.37$, and living condition with $M=3.00$ except that health grant with $M=3.45$ were indicated as highly satisfied. In 2015, it also indicated those respondents' ages below 30 rated health grant as the highest with $M=3.45$, followed by nutrition grant with $M=3.39$, education grant with $M=3.37$, and the least was living conditions with $\mathrm{M}=3.00$. On the other hand, respondents with ages 30 and above rated education grant as the highest with $M=3.32$, followed by health grant with $M=3.31$, then nutrition grant with $M=3.23$, and the least was the living condition with $\mathrm{M}=2.99$. 


\section{Pantawid Pamilyang Pilipino Program (4Ps) Beneficiaries: An Analysis of Their Satisfaction Level}

However, in 2020, it showed that health grant with $M=3.40$ and living condition with $M=3.33$ were interpreted as highly satisfied while nutrition grant with $\mathrm{M}=3.46$ and education grant with $\mathrm{M}=3.46$ were interpreted as highly satisfied. When grouped according to 30 and above, it showed that in 2015 the satisfaction level of the CCT program was highly satisfied in terms of health grant, education grant, nutrition grant, and living condition. The 2020 survey indicated that nutrition grant with $\mathrm{M}=3.39$ and living condition with $\mathrm{M}=3.37$ remained as satisfied. However, health grant with 3.44 and education grant at 3.49 indicated as highly satisfied. Further 2020 survey indicated that those respondents' ages above 30 rated education grant as the highest with $M=3.32$, followed by health grant with $M=3.31$, nutrition grant $M=3.23$, and the least was living condition with $M=2.99$. On the other hand, respondents with ages below 30 in 2020 revealed that respondents rated nutrition grant and education grant as the highest with $M=3.46$, followed by health grant with $M=3.40$, and the least was living condition with $M=3.33$. It was revealed that respondents' satisfaction level to 4Ps program according to age was higher in 2020 than in 2015, scored the highest at education grant which increased to a highly satisfied level in 2020.

Table 4. Satisfaction level of the 4Ps beneficiaries During the Year 2015 and Year 2020 when GroupedAccording to Sex

\begin{tabular}{|c|c|c|c|c|}
\hline & \multicolumn{2}{|r|}{2015} & \multicolumn{2}{|r|}{2020} \\
\hline $\begin{array}{l}\text { Areas and } \\
\text { Variables }\end{array}$ & Mean & $\begin{array}{c}\text { Verbal } \\
\text { Interpretation }\end{array}$ & Mean & $\begin{array}{c}\text { Verbal } \\
\text { Interpretation }\end{array}$ \\
\hline \multicolumn{5}{|l|}{ Health } \\
\hline Female & 3.56 & Highly Satisfied & 3.43 & Highly Satisfied \\
\hline Male & 3.37 & Satisfied & 3.56 & Highly Satisfied \\
\hline As A Whole & 3.47 & Highly Satisfied & 3.50 & Highly Satisfied \\
\hline \multicolumn{5}{|l|}{ Nutrition } \\
\hline Female & 3.19 & Satisfied & 3.37 & Satisfied \\
\hline Male & 3.32 & Satisfied & 3.60 & Highly Satisfied \\
\hline As A Whole & 3.26 & Satisfied & 3.49 & Highly Satisfied \\
\hline \multicolumn{5}{|l|}{ Education } \\
\hline Female & 3.19 & Satisfied & 3.48 & Satisfied \\
\hline Male & 3.36 & Satisfied & 3.60 & Highly Satisfied \\
\hline As A Whole & 3.28 & Satisfied & 3.54 & Highly Satisfied \\
\hline \multirow{2}{*}{\multicolumn{5}{|c|}{$\begin{array}{l}\text { Living } \\
\text { Condition }\end{array}$}} \\
\hline & & & & \\
\hline Female & 2.88 & Satisfied & 3.36 & Satisfied \\
\hline Male & 3.01 & Satisfied & 3.52 & Highly Satisfied \\
\hline As A Whole & 2.95 & Sotisfied & 3.44 & Highly Satisfied \\
\hline
\end{tabular}

Table 4 shows the satisfaction level of the 4Ps beneficiaries of Barangay VI, Victorias City, Negros Occidental during the year 2015 and year 2020 according to sex. Overall, the satisfaction level of 4Ps beneficiaries in 2015 with females was satisfied in terms of nutrition grant with $M=3.19$, education grant with $M=3.19$, and living condition with $M=2.878$ except that health grant with $\mathrm{M}=3.43$ were indicated as satisfied. The 2015 survey also indicated that female respondents rated health grant as the highest with $M=3.56$, followed by nutrition grant and education grant with $M=3.19$, and the least was living conditions with $M=2.88$. On the other hand, male respondents rated health grants as the highest with $M=3.37$, followed by education grant with $M=3.36$, then nutrition grant with $M=3.32$, and the least was the living condition with $M=3.01$.

However, in 2020, it showed that health grant with $M=3.43$ and education grant with $M=3.48$ were interpreted as satisfied. However, nutrition grant with $\mathrm{M}=3.37$ and living condition with $\mathrm{M}=3.36$ were interpreted as satisfied. When grouped according to males, in the year 2015 it showed that the satisfaction level to CCT program was satisfied in terms of health grant $M=3.37$, education grant with $M=3.32$, nutrition grant with $M=3.36$, and living condition with $M=3.01$. However, in 2020 , it indicated that the satisfaction was satisfied in terms of health grant with $M=3.56$, nutrition grant with $M=3.60$, education grant with 3.60 , and living condition with $\mathrm{M}=3.52$.

Further, the 2020 survey indicated that female respondents rated education grant as the highest with $M=3.48$, followed by 


\section{Pantawid Pamilyang Pilipino Program (4Ps) Beneficiaries: An Analysis of Their Satisfaction Level}

health grant with $M=3.43$, nutrition grant with $M=3.37$, and the least was living condition with $M=3.36$. On the other hand, male respondents rated nutrition grant and education grant as the highest with $M=3.60$, followed by health grant with $M=3.56$, and the least was living condition with $\mathrm{M}=3.52$.

It revealed that respondents' satisfaction level to 4Ps program according to sex was higher in 2020 than in 2015 . It scored the highest at education grant and health grant and lowest at living condition. Further, nutrition grant, education grant, and living condition increased to a highly satisfying level in 2020.

Table 5. Satisfaction level of the 4Ps Beneficiaries During the Year 2015 and Year 2020 when Grouped According to Civil Status

\begin{tabular}{|c|c|c|c|c|}
\hline & & 2015 & & 2020 \\
\hline $\begin{array}{l}\text { Areas amd } \\
\text { Variables }\end{array}$ & Miean & $\begin{array}{c}\text { Verbal } \\
\text { Interpretation }\end{array}$ & Mean & $\begin{array}{c}\text { Verbal } \\
\text { Interpretation }\end{array}$ \\
\hline \multicolumn{5}{|l|}{ Health } \\
\hline Married & 3.43 & Highly Satisfied & 3.46 & Highly Satisfied \\
\hline Separated & 3.25 & Satisfied & 3.45 & Highly Satisfied \\
\hline Widow & 3.07 & Satisfied & 3.44 & Highly Satisfied \\
\hline Single & 3.00 & Satisfied & 3.44 & Highly Satisfied \\
\hline \multicolumn{5}{|l|}{ Parent } \\
\hline As $A$ Whole & 3.19 & Satisfied & 3.45 & Highiy Satisfied \\
\hline \multicolumn{5}{|l|}{ Nutrition } \\
\hline Married & 3.36 & Satisfied & 3.46 & Highly Satisfied \\
\hline Separated & 3.25 & Satisfied & 3.45 & Highly Satisfied \\
\hline Widow & 2.79 & Satisfied & 3.26 & Satisfied \\
\hline $\begin{array}{l}\text { Single } \\
\text { As } A \text { VRole }\end{array}$ & $\begin{array}{l}3.25 \\
3.16\end{array}$ & $\begin{array}{l}\text { Satisfied } \\
\text { Sotisfied }\end{array}$ & $\begin{array}{l}3.39 \\
3.39\end{array}$ & $\begin{array}{l}\text { Satisfied } \\
\text { Satisfied }\end{array}$ \\
\hline \multicolumn{5}{|l|}{ Education } \\
\hline Married & 3.35 & Satisfied & 3.52 & Satisfied \\
\hline Separated & 3.67 & Satisfied & 3.54 & Highly Satisfied \\
\hline Widow & 3.07 & Satisfied & 3.35 & Satisfied \\
\hline Single & 3.25 & Satisfied & 3.49 & Highly Satisfied \\
\hline \multicolumn{5}{|l|}{ Parent } \\
\hline $\begin{array}{l}\text { As } A \text { Whole } \\
\text { Living }\end{array}$ & 3.34 & Satisfied & 3.48 & Highily Satisfied \\
\hline \multicolumn{5}{|l|}{ Condition } \\
\hline Married & 3.03 & Satisfied & 3.37 & Satisfied \\
\hline Separated & 3.08 & Satisfied & 3.45 & Highly Satisfied \\
\hline Widow & 2.92 & Satisfied & 3.44 & Highly Satisfied \\
\hline Single & 2.25 & Fairly Satisfied & 3.37 & Satisfied \\
\hline \multicolumn{5}{|l|}{ Parent } \\
\hline As $A$ Wrole & $2.8 Z$ & Satisfied & $3.4 I$ & Highly Satisfied \\
\hline
\end{tabular}

Table 5 shows the satisfaction level of the 4Ps beneficiaries of Barangay VI, Victorias City, Negros Occidental during 2015 and 2020 according to civil status. Overall, the satisfaction of married 4Ps beneficiaries in 2015 was satisfied in terms of nutrition grant with $M=3.36$, education grant with $M=3.35$, and living condition with $M=3.03$. Only that health grant with $M=3.43$ were highly satisfied. However, in 2020, it showed that education grant with $M=3.52$ and living condition with $M=3.37$ remained satisfied. However, nutrition grant with $M=3.46$ and health grant with $M=3.46$ were highly satisfied. When grouped according to separated parent-beneficiaries, it showed that in the year 2015 the satisfaction to CCT program was satisfied in terms of health grant $M=3.25$, nutrition grant with $M=3.25$, education grant with $M=3.67$, and living condition with $M=3.08$. The 2015 survey also indicated that married respondents rated health grant as the highest with $M=3.43$, followed by nutrition grant with $M=3.36$, then education grant with $M=3.35$ and the least were living condition with $M=3.03$. Separated respondents rated education grant as the highest with $M=3.67$, followed by health and nutrition grants with $M=3.25$, and the least was the living condition with $M=3.08$. Widow respondents rated health grant and education grant as the highest with $M=3.07$, followed by living condition with $\mathrm{M}=2.92$, and the least was nutrition grant with $\mathrm{M}=2.79$. Single parent respondents rated nutrition grant and education grant as the highest with $M=3.25$, followed by health grant with $M=3.00$, and the least was living condition with $M=2.25$.

However, in 2020, it indicated that the satisfaction level was satisfied in terms of health grant with $M=3.45$, nutrition grant with $M=3.45$, education grant with $M=3.54$, and living condition with $M=3.45$. When grouped according to widow parentbeneficiaries, it showed that in 2015 the satisfaction to CCT program was satisfied in terms of health grant $M=3.07$, nutrition grant with $M=2.79$, education grant with $M=3.07$, and living condition with $M=2.92$. Even if nutrition grant and living condition have lower mean scores, still widow parent-beneficiaries were satisfied. However, in 2020, it indicated that the level of satisfaction remained satisfied in terms of nutrition grant with $M=3.26$ and education grant with $M=3.35$. However, health grant with $M=3.44$ and living condition with $M=3.44$ have significantly indicated as highly satisfied. When grouped according to single parent beneficiaries, it showed that in the year 2015 the satisfaction was satisfied in terms of health grant with $M=3.00$, nutrition grant $M=3.25$, and education grant with $M=3.25$ except for living condition with $M=2.25$ which indicated fairly satisfied. 


\section{Pantawid Pamilyang Pilipino Program (4Ps) Beneficiaries: An Analysis of Their Satisfaction Level}

However, the 2020 survey, showed that nutrition grant with $M=3.39$ and living condition with $M=3.37$ remained satisfied while health grant with $M=3.44$ and education grant with $M=3.49$ were satisfied. Further, the 2020 survey indicated that married respondents rated education grant as the highest with $\mathrm{M}=3.52$, followed by health grant and nutrition grant with $\mathrm{M}=3.46$, and the least was living condition with $M=3.37$. Separated respondents rated education grant as the highest with $M=3.54$, and the least were health grant, nutrition grant, and living condition with $M=3.45$. Widow respondents rated health grant and living condition as the highest with $M=3.44$, followed by education grant with $M=3.35$, and the least was nutrition grant with $M=3.26$. Single parent respondents rated education grant as the highest with $M=3.49$, followed by health grant with $M=3.44$, then nutrition grant with $M=3.39$ and the least were living condition with $M=3.37$. It revealed that respondents' satisfaction level to 4Ps program according to civil status was higher in 2020 than in 2015. It scored the highest at education grant and lowest at living condition. Further, health grant, education grant, and living condition increased to a highly satisfying level in 2020.

Table 6. Satisfaction level of the 4Ps beneficiaries During year 2015 and year 2020

\begin{tabular}{|c|c|c|c|c|}
\hline & \multicolumn{2}{|r|}{2015} & \multicolumn{2}{|r|}{2020} \\
\hline $\begin{array}{l}\text { Areas and } \\
\text { Variables }\end{array}$ & Mean & $\begin{array}{c}\text { Verbal } \\
\text { Interpretation }\end{array}$ & Mean & $\begin{array}{c}\text { Verbal } \\
\text { Interpretation }\end{array}$ \\
\hline \multicolumn{5}{|l|}{ Health } \\
\hline Laborer & 3.43 & Highly Satisfied & 3.43 & Highly Satisfied \\
\hline Driver & 3.25 & Satisfied & 3.20 & Satisfied \\
\hline Vendor & 3.46 & Highly Satisfied & 3.45 & Highly Satisfied \\
\hline Wo Work & 3.30 & Satisfied & 3.54 & Highly Satisfied \\
\hline As A Whole & 3.36 & Satisfied & 3.41 & Highly Satisfied \\
\hline \multicolumn{5}{|l|}{ Nutrition } \\
\hline Laborer & 3.32 & Satisfied & 3.40 & Satisfied \\
\hline Driver & 3.25 & Satisfied & 3.28 & Satisfied \\
\hline Wendor & 3.37 & Satisfied & 3.39 & Satisfied \\
\hline No Work & 3.40 & Satisfied & 3.42 & Highly Satisfied \\
\hline As A Whole & 3.34 & Satisfied & 3.37 & Sotisfied \\
\hline \multicolumn{5}{|l|}{ Education } \\
\hline Laborer & 3.35 & Satisfied & 3.46 & Highly Satisfied \\
\hline Driver & 3.26 & Satisfied & 3.52 & Highly Satisfied \\
\hline Vendor & 3.46 & Highly Satisfied & 3.45 & Highly Satisfied \\
\hline Wo Work & 3.50 & Highly Satisfied & 3.54 & Highly Satisfied \\
\hline As A Whole & 3.39 & Satisfied & 3.49 & Highly Satisfied \\
\hline Living & & & & \\
\hline \multicolumn{5}{|l|}{ Condition } \\
\hline Laborer & 2.95 & Satisfied & 3.38 & Satisfied \\
\hline Driver & 3.01 & Satisfied & 3.36 & Satisfied \\
\hline Vendor & 3.14 & Satisfied & 3.37 & Satisfied \\
\hline Wo Work & 3.00 & Satisfied & 3.35 & Satisfied \\
\hline $\begin{array}{l}\text { As } A \text { Whole } \\
\text { As a Whole }\end{array}$ & 3.03 & Satisfied & 3.37 & Sotisfied \\
\hline
\end{tabular}

Table 6 shows the satisfaction level of the 4Ps beneficiaries of Barangay VI, Victorias City, Negros Occidental during 2015 and 2020 according to occupation. The satisfaction level of laborer 4Ps parent-beneficiaries in 2015 was satisfied in terms of nutrition grant with $M=3.32$, education grant with $M=3.35$, and living condition with $M=2.95$ with the exception that health grant with $M=3.43$ indicated as highly satisfied. However, in 2020 , it showed that nutrition grant with $M=3.40$ and living condition with $M=3.38$ remained satisfied. However, health grant with $M=3.43$ and education grant with $M=3.46$ were interpreted as highly satisfied. When grouped according to driver parent-beneficiaries, it showed that in 2015 the satisfaction to CCT program was satisfied in terms of health grant $M=3.25$, nutrition grant with $M=3.25$, education grant with $M=3.26$, and living condition with $M=3.01$. The 2015 survey also indicated that laborer respondents rated health grant as the highest with $M=3.43$, followed by education grant with $M=3.35$, then nutrition grant with $M=3.32$ and the least were living condition with $M=2.95$. Driver respondent rated education grant as the highest with $M=3.26$, followed by education grant with $M=3.26$, then health grant with $M=3.25$, and the least was the living condition with $M=3.01$. Vendor respondents rated health grant and education grant as the highest with $M=3.46$, followed by nutrition grant with $M=3.37$, and the least was living condition with $M=3.14$. Respondents with no work rated education grant as the highest with $M=3.50$, followed by nutrition grant with $M=3.40$, then health grant with $M=3.30$ and the least were living condition with $M=3.00$. 


\section{Pantawid Pamilyang Pilipino Program (4Ps) Beneficiaries: An Analysis of Their Satisfaction Level}

However, the 2020 survey, showed that health grant with $M=3.54$, nutrition grant with $M=3.42$, and education grant with $M=3.54$ were highly satisfied except that living condition with $M=3.35$ remained satisfied. Overall, it indicated that the satisfaction level to the CCT program in 2015 and 2020 according to civil status remained satisfied except that health grant and education grant increased their level remained highly satisfied in 2020. It revealed that 4Ps parent-beneficiaries when grouped according to civil status were more satisfied in terms of health and education grants in 2020 than in 2015 . Further, the 2020 survey indicated that laborer respondents rated education grant as the highest with $\mathrm{M}=3.46$, followed by health grant with $M=3.43$, then nutrition grant with $M=3.40$ and the least were living condition with $M=3.38$. Driver respondents rated education grant as the highest with $M=3.52$, followed by living condition with $M=3.36$, then nutrition grant with $M=3.28$ and the least were health and nutrition grants with $M=3.20$. Vendor respondents rated health grant and education grant as the highest with $M=3.45$, followed by nutrition grant with $M=3.39$, and the least was living condition with $M=3.37$. Respondents with no work rated education grant and health grant as the highest with $M=3.54$, followed by nutrition grant with $M=3.42$, and the least was living condition with $M=3.35$. It revealed that respondents' satisfaction level to 4Ps program according to occupation was higher in 2020 than in 2015. It scored the highest at education grant and lowest at living condition. Further, health grant and education grant increased to a highly satisfying level in 2020.

Table 7. Satisfaction level of the 4Ps beneficiaries During the Year 2015 and Year 2020 According to Number of Children

\begin{tabular}{|c|c|c|c|c|}
\hline & \multicolumn{2}{|r|}{2015} & \multicolumn{2}{|r|}{2020} \\
\hline $\begin{array}{l}\text { Areas and } \\
\text { Variables }\end{array}$ & Mean & $\begin{array}{c}\text { Verbal } \\
\text { Interpretation }\end{array}$ & Mean & $\begin{array}{c}\text { Verbal } \\
\text { Interpretation }\end{array}$ \\
\hline \multicolumn{5}{|l|}{ Health } \\
\hline $1 \cdot 3$ & 3.36 & Satisfied & 3.56 & Highly Satisfied \\
\hline 4 and above & 3.40 & Highly Satisfied & 3.33 & Satisfied \\
\hline As A Whole & 3.38 & Satisfied & 3.45 & Highly Satisfied \\
\hline \multicolumn{5}{|l|}{ Nutrition } \\
\hline $1 \cdot 3$ & 3.26 & Satisfied & 3.53 & Highly Satisfied \\
\hline 4 and above & 3.38 & Satisfied & 3.28 & Satisfied \\
\hline As A Whole & 3.32 & Satisfied & 3.41 & Highly Satisfied \\
\hline \multicolumn{5}{|l|}{ Education } \\
\hline $1 \cdot 3$ & 3.33 & Satisfied & 3.58 & Highly Satisfied \\
\hline 4 and above & 3.37 & Satisfied & 3.42 & Highly Satisfied \\
\hline As A Whole & 3.37 & Satisfied & 3.50 & Highly Satisfied \\
\hline \multicolumn{5}{|l|}{ Living } \\
\hline \multicolumn{5}{|l|}{ Condition } \\
\hline $1 \cdot 3$ & 2.94 & Satisfied & 3.52 & Satisfied \\
\hline 4 and above & 3.07 & Satisfied & 3.24 & Satisfied \\
\hline As A Whole & 3.01 & Satisfied & 3.38 & Satisfied \\
\hline
\end{tabular}

Table 7 shows the satisfaction level of the 4Ps beneficiaries of Barangay VI, Victorias City, Negros Occidental during the year 2015 and year 2020 according to the number of children. The satisfaction level of 4Ps parent- beneficiaries in 2015 with 1-3 number of children indicated satisfied in terms of health grant with $M=3.36$, nutrition grant with $M=3.26$, education grant with $M=3.33$, and living condition with $M=2.94$. However, in 2020 , it showed that health grant with $M=3.56$, nutrition grant with $M=3.53$, education grant with $M=3.58$, and living conditions with $M=3.52$ were highly satisfied. When grouped according to parent-beneficiaries with 4 and above several children, it showed that in 2015 the satisfaction level to CCT program was satisfied in terms of health grants $M=3.40$, nutrition grants with $M=3.38$, education grants with $M=3.37$, and living condition with $M=3.07$. The 2015 survey also indicated that respondents with 1-3 children, rated health grants as the highest with $M=3.36$, followed by education grants with $M=3.33$, then nutrition grants with $M=3.26$ and the least were living condition with $M=2.94$. On the other hand, respondents with 4 and more children, rated health grants as the highest with $\mathrm{M}=3.40$, followed by nutrition grants with $\mathrm{M}=3.38$, then education grants with $\mathrm{M}=3.37$, and the least was the living condition with $\mathrm{M}=3.07$.

However, in 2020, it indicated that the satisfaction level remained satisfied in terms of health grant with $M=3.33$, nutrition grant with $M=3.28$, and living condition with $M=3.24$ except that education grant with $M=3.52$ were highly satisfied. Further, the 2020 survey indicated that respondents with 1-3 children, rated education grants as the highest with $M=3.58$, followed by health 


\section{Pantawid Pamilyang Pilipino Program (4Ps) Beneficiaries: An Analysis of Their Satisfaction Level}

grants with $M=3.56$, then nutrition grants with $M=3.53$, and the least was living condition with $M=3.52$. On the other hand, respondents with 4 and more children, rated education grants as the highest with $M=3.42$, followed by health grants with $M=3.33$, then nutrition grants with $M=3.28$, and the least was the living condition with $M=3.24$.

It revealed that respondents' satisfaction level with the 4Ps program according to the number of children was higher in 2020 than in 2015. It scored the highest at education grants and health grants and lowest at living conditions. Further, health grants, nutrition grants, and education grants increased to a highly satisfying level in 2020.

Table 8. Satisfaction level of the 4Ps Beneficiaries During the Year 2015 and Year 2020 when Grouped According to Educational Qualification

\begin{tabular}{|c|c|c|c|c|}
\hline & \multicolumn{2}{|r|}{2015} & \multicolumn{2}{|r|}{2020} \\
\hline $\begin{array}{l}\text { Areas and } \\
\text { Variables }\end{array}$ & Mean & $\begin{array}{c}\text { Verbal } \\
\text { Interpretation }\end{array}$ & Mean & $\begin{array}{c}\text { Verbal } \\
\text { Interpretation }\end{array}$ \\
\hline \multicolumn{5}{|l|}{ Health } \\
\hline Elementary & 3.35 & Satisfied & 3.39 & Satisfied \\
\hline High School & 3.44 & Highly Satisfied & 3.44 & Highly Satisfied \\
\hline College Level & 3.00 & Satisfied & 3.44 & Highly Satisfied \\
\hline College Graduate & 3.00 & Satisfied & 4.00 & Highly Satisfied \\
\hline As A Whole & 3.20 & Satisfied & 3.57 & Highly Satisfied \\
\hline \multicolumn{5}{|l|}{ Nutrition } \\
\hline Elementary & 3.26 & Satisfied & 3.43 & Highly Satisfied \\
\hline High School & 3.38 & Satisfied & 3.36 & Satisfied \\
\hline College Level & 2.92 & Satisfied & 3.40 & Satisfied \\
\hline College Graduate & 3.25 & Satisfied & 4.00 & Highly Satisfied \\
\hline $\begin{array}{l}\text { As A Whole } \\
\text { Education }\end{array}$ & 3.20 & Satisfied & 3.55 & Highly Satisfied \\
\hline Elementary & 3.30 & Satisfied & 3.54 & Highly Satisfied \\
\hline High School & 3.40 & Satisfied & 3.45 & Highly Satisfied \\
\hline College Level & 3.07 & Satisfied & 3.52 & Highly Satisfied \\
\hline College Graduate & 3.25 & Satisfied & 4.00 & Highly Satisfied \\
\hline As A Whole & 3.26 & Satisfied & 3.63 & Highly Satisfied \\
\hline \multicolumn{5}{|l|}{ Living Condition } \\
\hline Elementary & 3.06 & Satisfied & 3.43 & Satisfied \\
\hline High School & 3.02 & Satisfied & 3.34 & Satisfied \\
\hline College Level & 2.61 & Satisfied & 3.30 & Satisfied \\
\hline College Graduate & 2.50 & Satisfied & 3.80 & Satisfied \\
\hline As A Whole & 2.80 & Satisfied & 3.47 & Highly Satisfied \\
\hline
\end{tabular}

Table 8 shows the satisfaction level of the 4Ps beneficiaries of Barangay VI, Victorias City, Negros Occidental during 2015 and 2020 according to educational qualification. The satisfaction level of elementary graduate 4Ps parent-beneficiaries in 2015 was satisfied in terms of health grant with $M=3.35$, nutrition grant with $M=3.26$, education grant with $M=3.30$, and living condition with $M=3.06$. However, in 2020, it showed that the satisfaction level of the CCT program remained satisfied in terms of health grant with $M=3.39$ and living condition with $M=3.43$. When grouped according to high school parent-beneficiaries, it showed that in 2015 the satisfaction level to CCT program was satisfied in terms of nutrition grant $M=3.38$, education grant with $M=3.40$, and living condition with $M=3.02$ except that health grant with $M=3.44$ were highly satisfied. However, in 2020 , it indicated that the satisfaction level was satisfied in terms of nutrition grant with $M=3.36$ and living condition with $M=3.34$ except that health grant with $M=3.44$ and education grant with $M=3.45$ were highly satisfied. When grouped according to college-level 4Ps parent-beneficiaries, it showed that in 2015 the satisfaction level to CCT program was satisfied in terms of health grant with $M=3.00$, nutrition grant $M=2.92$, education grant with $M=3.07$, and living condition with $M=2.61$. However, in 2020 , it indicated that the satisfaction level remained satisfied in terms of nutrition grant with $M=3.40$ and living condition with $M=3.30$. However, health grant with $M=3.44$ and education grant with $M=3.52$ have significantly increased to a highly satisfied. When grouped according to college graduate 4Ps parent-beneficiaries, it showed that in 2015 the satisfaction level was satisfied in terms of health grant with $M=3.00$, nutrition grant $M=3.25$, education grant with $M=3.25$, and living condition with $M=2.50$. The 2015 survey also indicated that elementary graduate respondents rated health grant as the highest with $M=3.35$, followed by education grant with $M=3.30$, then nutrition grant with $M=3.26$ and the least were living condition with $M=3.06$. The high school graduate respondents rated health grant as the highest with $M=3.44$, followed by education grant with 


\section{Pantawid Pamilyang Pilipino Program (4Ps) Beneficiaries: An Analysis of Their Satisfaction Level}

$M=3.40$, then nutrition grant with $M=3.38$, and the least was the living condition with $M=3.02$. The college-level respondents rated education grant as the highest with $M=3.07$, followed by health grant with $M=3.00$, then nutrition grant with $M=2.92$ and the least were living conditions with $M=2.61$. College graduate respondents rated education grant and nutrition grant as the highest with $M=3.25$, followed by health grant with $M=3.00$, and the least was living condition with $M=2.50$.

However, the 2020 survey, showed that health grant with $M=4.00$, nutrition grant with $M=4.00$, and education grant with $M=4.00$ were highly satisfied except that living condition with $M=3.80$ remained satisfied. Overall, it indicated that the satisfaction level to the CCT program in 2015 and 2020 according to civil status remained satisfied except that health grant and education grant were highly satisfied in 2020. Further, the 2020 survey indicated that elementary graduate respondents rated education grant as the highest with $M=3.54$, followed by nutrition grant and living condition with $M=3.43$, and the least was health grant with $\mathrm{M}=3.39$.

The high school graduate respondents rated education grant as the highest with $M=3.45$, followed by health grant with $M=3.44$, then nutrition grant with $M=3.36$, and the least was the living condition with $M=3.34$. The college-level respondents rated education grant as the highest with $M=3.52$, followed by health grant with $M=3.44$, then nutrition grant with $M=3.40$ and the least were living condition with $M=3.30$. College graduate respondents rated education grant, nutrition grant, and health grant as the highest with $M=4.00$, and the least was living condition with $M=3.80$. Finally, it revealed that there was a significant difference in the satisfaction level of the 4Ps parent-beneficiaries of Barangay VI, Victorias City, Negros Occidental during the year 2015 and year 2020. That the satisfaction level was higher in 2020 with $M=3.43$ indicated highly satisfied and lower in 2015 with $M=3.26$ indicated as satisfied. It revealed that respondents' satisfaction level to 4Ps program according to educational qualification was higher in 2020 than in 2015. It scored the highest at education grant and lowest at living condition. Further, health grant, nutrition grant, education grant, and living condition increased to a highly satisfying level in 2020.

\section{FINDINGS}

The demographic profile of 4Ps parent-beneficiaries in 2015 and 2020 revealed approximately $41.2 \%$ of 30 years old and above new 4Ps beneficiaries were added to the program in Barangay VI by 2020 . When grouped according to sex, it revealed that the number of female 4Ps parent-beneficiaries significantly decreased by $2.6 \%$ and males increased by $2.6 \%$ in 2020 . Overall, the majority of 4Ps beneficiaries were female with 425 (91.20\%). Overall, the percentages of female parent-beneficiaries were higher than that of males. When grouped according to the civil status it shows a significant decrease in 2020 with married beneficiaries by $13.5 \%$ and those who were separated by $1.2 \%$. However, a significant increase was obvious with widowed parent-beneficiaries by $7.1 \%$ and the single parent by $9.9 \%$.

Overall, the majority of 4Ps beneficiaries by age are married with 359 (77.04\%). When it comes to occupation there was a significant decrease in the following 4 Ps beneficiaries in the year 2020: drivers with 16.4\%, and vendors with $9.8 \%$. However, those beneficiaries who have no work have significantly increased by $17.4 \%$ and laborers by $8.8 \%$ in 2020 . The rise of people who have no work and laborers was probably because of the effect of the Covid 19 pandemic. Due to the Covid-19 outbreak and the lockdown shuttering thousands of businesses, Filipinos have lost their jobs this year, with the unemployment rate reaching $10.4 \%$, the highest in 15 years, according to the government. Overall, the majority of the educational background of 4Ps beneficiaries of Barangay VI was high school followed by elementary level and graduates. When grouped according to the number of children, there was a significant decrease by $2.6 \%$ with parent-beneficiaries with $1-3$ numbers of children and $2.6 \%$ increase to 4Ps beneficiaries with 4 and above several children. Overall, the majority of the 4Ps beneficiaries have 1-3 children per household. In terms of family size, most of them belong to small families with one to three children..

When grouped according to educational qualification, there was a significant decrease in 4Ps beneficiaries with high school educational level by $3.8 \%$ and high school educational level by $0.7 \%$ in 2021 . On the other hand, there was an increase to college-level parent-beneficiaries by $4.8 \%$ and college graduates by $0.1 \%$. The majority of 4 Ps beneficiaries by educational qualification was at high school with 284 (60.95\%) which found out that most parent respondents parents were high school graduates and engaged in non-professional occupations. Further, college-level parent-beneficiaries have had increased by $4.8 \%$ but with no work increased by $69 \%$. It indicated that 4Ps beneficiaries were able to finish their basic education and have reached higher education levels. However, there was also an obvious decrease of 4ps beneficiaries from 2015 to 2020 with the following: 30 and above decreased (46.8\%), females (2.6\%), drivers (16.4\%) and vendors (9.8\%), elementary educational qualification (3.8\%) and high school (0.7\%). The satisfaction level of 4Ps parent-beneficiaries to CCT remained at a satisfying level from 2015 to 2020 in terms of nutrition grants and living conditions only. On the other hand, health grants and education grants have significantly indicated as highly satisfied by the year 2020. It revealed that the 4Ps beneficiaries were highly satisfied with the program than they used to be in 2015. 


\section{Pantawid Pamilyang Pilipino Program (4Ps) Beneficiaries: An Analysis of Their Satisfaction Level}

Further from 2010 to 2016, the program consistently registered above $88 \%$ compliance with the health conditions of the program, such as deworming, immunization, and preventive check-ups, and according to the Impact Evaluation Wave 2, "more 4Ps mothers delivered in health facilities. Generally, it has brought satisfaction even in times of global pandemic. It further indicated that the following 4Ps beneficiaries: male, female, below 30, above 30, separated, widow, single parent, no work/job, with 1-3 children, college-level and graduate were more satisfied in the program in 2020 satisfaction survey than in 2015 in terms of health grants and living conditions. Significantly, residents of Barangay VI, Victorias City were more satisfied in the satisfaction survey in the year 2020 than in 2015 in terms of health grants and education grants. Overall, the year 2020 survey revealed that 4Ps parents-beneficiaries were highly satisfied with the program than that of the 2015 satisfaction survey significantly on health and education grants were statistically noted.

There was a significant difference in the satisfaction level of 4Ps parent-beneficiaries to the CCT program between the years 2015 and 2020. It was revealed that the satisfaction level was higher in 2020 than in 2015 in terms of health and education grants.

\section{CONCLUSIONS}

The demographic profile of 4Ps parent-beneficiaries of Barangay VI, Victorias City, Negros Occidental during 2015 and 2020 shows that majority of them were above 30 with 349 (74.89\%), female with 425 (91.20\%), married with 359 (77.04\%), a laborer with 268 (57.51\%), with 1-3 number of children with 261 (56\%), and high school level of educational attainment with 284 (60.95\%). Further, it indicated that there was an increasing trend in the 4Ps parent-beneficiaries in 2020 with the following: above 30 years old $(41.2 \%)$ widow $(7.1 \%)$, single parent $(9.9 \%)$, no work (17.4\%), laborers (8.8\%), college-level (4.8\%) and college graduates $(0.1 \%)$. The increasing number of $4 \mathrm{Ps}$ parent-beneficiaries with college-level or graduate indicated that the new members' 4Ps parent-beneficiaries have finished basic education and even tertiary level. It implies that the education system in the Philippines has positively impacted the educational attainment of the CCT program. Also, the rise of 4Ps parent-beneficiaries who have no work or laborers was probably because of the effect of the Covid 19 pandemic. Moreover, it revealed the decreasing trend in the year 2020 with the following 4Ps parent-beneficiaries: below 30 years old (41.2\%) married (13.5\%), separated (1.2\%), with 1-3 children (2.6\%), with the elementary educational level (3.8\%), and those with high school educational level $(0.7 \%)$. The decrease of beneficiaries who's 30 and above indicated that old members were no longer a part of the government program in the year 2020. Further, the decrease of members whose educational background was either elementary or high school indicated that basic education has mostly been met by Filipinos living in poverty.

The satisfaction level of 4Ps beneficiaries to CCT has significantly increased to a high level of satisfaction by 2020 in terms of health grants and education grants. In education, the CCT program has helped increase the low performance of learners into better performance. The retention rate of elementary schools dramatically decreased. The overall satisfaction increased in the year 2020 which revealed that 4Ps parents-beneficiaries were highly satisfied with the program in 2020 than that of the 2015 satisfaction survey, significantly on health and education grants were statistically noted.

There was a significant difference in the satisfaction level of 4Ps parent- beneficiaries to the CCT program. It was revealed in the survey that the satisfaction level was higher in 2020 than in 2015 especially in terms of health and education grants. It implies enhanced health practices, improved uptake of barangay health care services, and increased awareness of health issues. In education, it changed the behavior of learners and their attitude towards learning. The program has helped increase the low performance of learners into better performance.

\section{Recommendations}

1. Conduct a seminar on sustainable programs that would enhance the living conditions and nutrition of the locals.

2. Find out the factors why nutrition grants and living conditions of 4Ps student and parent-beneficiaries have not increased.

3. Conduct a study that would find out the significant impact of the CCT program on the lives of previous 4Ps beneficiaries who graduated from the program.

4. Conduct a tracer study of 4Ps student beneficiaries about their current employability status.

5. Examine the level of academic performance and health status of 4Ps student beneficiaries since these two areas have significantly increased in 2020 than 2015.

6. Find out the underlying causes of low satisfaction levels on nutrition grants and living conditions as a basis for improving the program.

\section{REFERENCES}

1) Asian Development Bank (2020). Report and Recommendation of the President to the Board of Directors. Retrieved on: 


\section{Pantawid Pamilyang Pilipino Program (4Ps) Beneficiaries: An Analysis of Their Satisfaction Level}

July 16, 2021. Retrieved from: https://www.adb.org/sites/default/files/project-documents/52257/52257-001-rrpen.pdf

2) Braganza, C. (2018). The healthcare and education impacts of the Pantawid Pamilyang Pilipino Programme. Social Protection Org. Retrieved on April 3, 2021. Retrieved from: https://socialprotection.org/

3) Cepeda, C. (2020). Batch 2020: How Filipino college graduates job-hunted through the pandemic. Daily Inquirer. Retrieved on: July 16, 2021. Retrieved from: https://newsinfo.inquirer.net/1377399/batch-2020-how-filipino-collegegraduates-job-hunted-through-the-pandemic

4) Cho, Y. et al. (2020). Optimizing Pantawid for Nutrition. The World Bank. Retrieved on April 3, 2021. Retrieved from: http://documents1.worldbank.org/curated/en/951001604895440459/pdf/Optimizing-Pantawid-for-Nutrition.pdf

5) Commission on Audit (2017). Pantawid Pamilyang Pilipino Program. Performance Audit Report. Retrieved on: July 16, 2021. Retrieved from: https://www.coa.gov.ph/phocadownload/userupload/performance-audit-report/2017/PAO2017-01_4Ps.pdf

6) Congressional Policy and Budget Research Development House of Representatives (2017). Progress Report on the Pantawid Pamilyang Pilipino Program (4Ps). Retrieved on: July 16, 2021. Retrieved from:

https://cpbrd.congress.gov.ph/images/PDF\%20Attachments/Facts\%20in\%20Figures/FF2017-

18_Progress_Report_on_the_Pantawid.pdf

7) DSWD. Keeping children healthy and in school. Pantawid Pamilyang Pilipino Program 2nd Wave Impact Evaluation Results. Retrieved on April 3, 2021. Retrieved from: https://pantawid.dswd.gov.ph/wp-content/uploads/2018/09/IEWave-2-Executive-Summary.pdf

8) DSWD (2020). Monthly Report on Pantawid Pamilya Implementation. Retrieved on: July 16, 2021. Retrieved from: https://pantawid.dswd.gov.ph/wp-content/uploads/2020/09/2nd-Quarterly-Report-2020.pdf

9) Fernandez, C. and Pambid, R. (2017). Changes in Health-Seeking Habits of Pantawid Pamilyang Pilipino Program Beneficiaries in Barangay Bical Norte and Bani. PSU Journal of Education, Management and Social Sciences. Retrieved on April 3, 2021. Retrieved from: https://psurj.org/wp-content/uploads/2018/01/JEMSS_00010.pdf

10) Flores, M. (2019). Pantawid Pamilyang Pilipino Program (4Ps): Its Effect on the Academic Performance of StudentBeneficiaries in Calaba National High School in the Philippines. ResearchGate. Retrieved on April 3, 2021. Retrieved from: DOI: 10.5296/jpag.v9i2.14762

11) Gumanas, E. and Marticion, J. (2019). Level of Social Security Satisfaction Among Pantawid Pamilyang Pilipino Program (4P's)Grade 12 Beneficiaries of ZNNHS. Academia. Retrieved on April 3, 2021. Retrieved

from:https://www.academia.edu/40632280/Level_of_Social_Security_Satisfaction_Among_Pantawid_Pamilyang_Pilipi no_Program_4Ps_Grade_12_Beneficiaries_of_ZNNHS

12) Once, F. et al. (2019). Financial Literacy and Satisfaction of Beneficiaries to Pantawid Pamilyang Pilipino Program (4Ps): Evidence from the Poorest Countryside Areas of the Philippines. The Countryside Development Research Journal. Retrieved on April 3, 2021. Retrieved from: https://cdrj.ssu.edu.ph/index.php/CDRJ/article/view/163/123

13) Motilla, M. (2015). Pantawid Pamilyang Pilipino Program (4Ps): Assistance to Pupil's Education. Asia Pacific Journal of Education, Arts and Sciences. Retrieved on April 3, 2021. Retrieved from: http://oaji.net/articles/2015/17101440094900.pdf

14) Peñalba, E. (2019). Exploring the Health Outcomes of Conditional Cash Transfer Program in Rural Philippines. ResearchGate. Journal. Retrieved on: July 16, 2021. Retrieved from:

https://www.researchgate.net/publication/334285174_Exploring_the_Health_Outcomes_of_Conditional_Cash_Transf er_Program_in_Rural_Philippines

15) Philippine Women's University (2016). Beyond Compliance A Look into the Behavioral and Social Outcomes of the Pantawid Pilipinong Pamilya Program. Institute of Family Life and Children's Studies. Final Report. Retrieved on: July 16, 2021. Retrieved from: https://pantawid.dswd.gov.ph/wp-content/uploads/2018/08/Behavioral-and-Social-OutcomesStudy_Full-Report.pdf

16) Sasis, P. et al. (2019). The Impact of Pantawid Pamilyang Pilipino Program (4Ps) to its Beneficiaries. SMCC Business Administration Journal. Retrieved on April 3, 2021. Retrieved from:

https://sherj.smccnasipit.edu.ph/articles/business1/Sasis.pdf

17) UNICEF (2020). Making the 4Ps inclusive for all children of currently enrolled households. Retrieved on: July 16, 2021. Retrieved from: https://www.unicef.org/philippines/media/1961/file/Social\%20policy\%20brief\%20-\%204Ps.pdf

18) Ungogan, W. (2018). 4ps' Educational Reform for the Poor. HeraldExpress. Article. Retrieved on: July 16, 2021. Retrieved from: https://www.baguioheraldexpressonline.com/4ps-educational-reform-for-the-poor/ 